\title{
Impact of Cooperative Microfinance on the Performance of Women Entrepreneurship in Kwara State Nigeria
}

https://doi.org/10.21272/fmir.2(4).20--28.2018

\section{Popoola Mufutau Akanmu}

$\mathrm{PhD}$, Department of Business and Entrepreneurship, School of Business and Governance, Kwara state university Malete, Nigeria

\author{
Jones Olasimbo Clement \\ Department of Business and Entrepreneurship, School of Business and Governance, Kwara state university \\ Malete, Nigeria \\ Mande Samaila \\ Prof., School of postgraduate Studies, National Open University of Nigeria (NOUN), Nigeria
}

\begin{abstract}
This study assessed the effect of cooperative microfinance on the performance of women entrepreneurship in Kwara State, Nigeria. Specifically, the study identified entrepreneurial activities carried out by the women entrepreneurs, contributions of co-operative entrepreneurial activities to the women as well as identified constraints experienced by the cooperators in developing entrepreneurship among members. One hundred and seventy-six entrepreneurs show randomly selected out of three Cooperativeifteen Women engaging in Cooperative activities in Kwara State for the study using Taro Yamane's formula at 5\% error tolerance and $95 \%$ level of confidence. Instrument used for data collection was primarily questionnaire while data were analyzed using descriptive (frequency and percentage) and inferential statistics (Pearson Correlation analysis). Findings indicate that Group/Membership Increment $(=4.63)$, Group Development (=4.91), Skill Acquisition $(=3.98)$, Self Actualization $(=3.69)$, Economic growth $(=3.64)$ and Community Development $(=3.55)$ are major benefits accruing from co-operative entrepreneurial activities to the women cooperators. However, Inadequate Finance $(=4.87)$, Lack of access to raw materials $(=4.76)$, Maladministration $(=4.65)$, Inadequate market information $(=4.58)$, Lack of good Coordination $(=4.31)$, Lack of adequate and proper are major challenges experienced by the cooperators in developing entrepreneurship among members. The study recommends coordinated entrepreneurship training/education programme for the cooperators by the government in order to improve their entrepreneurial capacity and government intervention in the provision of necessary financial assistance to women in order to eliminate their poverty and improve their productivities.
\end{abstract}

Keywords: women entrepreneurship, cooperatives, microfinance, sustenance, development.

JEL Classification: J16, G00, G21.

(C) The Authors, 2018. This article is published with open access at Sumy State University.

Cite as: P. M. Akanmu, J. Ol. Clement, M. Samaila. (2018). Impact of Cooperative Microfinance on the Performance of Women Entrepreneurship in Kwara State Nigeria, Financial Markets, Institutions and Risks, 2(4), 20-28. https://doi.org/10.21272/fmir.2(4).20--28.2018

\section{Introduction}

Research from many countries shows that women are active in cooperatives and entrepreneurship and the establishment of microfinance was seen as a bright hope to make financial services accessible to a large segment of the potentially productive Nigerian population, which have had little or no access to financial services and empower them to contribute to rural transformation (Abiola, 2015). Organizations such as Cooperative Societies play an important role in the provision of microfinance to support women entrepreneurship in Nigeria. Despite the increase in the number of the microfinance institutions in Nigeria, access to finance is still considered as one of the major hindrances to women entrepreneurs.

Availability of microfinance derivatives has been viewed as a critical element in the development of women's MSMEs in Nigeria (Odetotayo,2016). Empowering women by promoting women's entrepreneurship in cooperatives has been identified as an important approach to alleviate rural poverty and promote sustainable development (FAO, 2016). Woman constitutes the family, which leads to Society and Nation. Female entrepreneurs make significant contributions to economic growth and to poverty reduction especially in developing country like Nigeria. 
Popoola (2018). Entrepreneurship refers to an individual ability to turn ideas into action, which includes creativity and innovation. This Entrepreneurship has been recognized by both developed and developing nations as an instrument for rapid and sustainable economic growth and development. It is considered as the engine of growth because it creates the needed manpower and skills for rapid growth, poverty reduction, empowerment creation, technical skills acquisition and income generation (Musa, 2014). It has been established that bulk of rural women in particular are significantly contributing to their national economies, but they are the poorest of poor, illiterate, ignorant, disease-ridden, occupying low social, economic and political status (Ochelle, 2014).

However, the operation of rural women entrepreneurship involves considerable risks, hard work, enormous sacrifice and sincerity of purpose which cut across various obstacles. Ayogu and Agu (2015), also recognized the various challenges and obstacles facing Women entrepreneurship particularly in Nigeria which include; capital inadequacy, unavailability of the required infrastructures, shortage of manpower. Furthermore, a growing population and environmental degradation are putting severe stress on natural farm productive resources, compelling more and more women to turn to non-agricultural activities for supplementary income and, in a growing number of cases, for alternative livelihood (FAO, 2016).

Also, the forces of globalization are increasingly exposing small-scale farmers, a majority of them women, to market conditions for which they are poorly prepared. The resulting transformation in the nature of smallscale agriculture demands that small farmers organize themselves into group and cooperative-based size rural enterprises. In order to transform themselves into successful rural entrepreneurs, the women need improved access to essential social services such as basic health care and education, safe drinking water and electricity, as well as a widening range of support services including credit, product and market information, technology, management skills and training in enterprise development. All these they easily access through their activities as cooperative members from government and non-governmental bodies (Umeh, et al., 2017). In view of the foregoing, this study was designed to assess the impact that the provision of cooperative microfinance has on the performance of women entrepreneurship in Kwara State of Nigeria.The study identified the major entrepreneurial activities carried out by the women entrepreneurs in Kwara state and sources of fund for their activities as well as the benefits of being a member of entrepreneurial cooperative. The study also identified constraints to entrepreneurial development in selected areas. Also, on cooperative, according to Popoola (2012), a cooperative is a business organization owned and operated by a group of individuals for their mutual benefit.

Cooperatives are defined by the international Cooperative Alliance's statement on the cooperative identity as Autonomous associations of person united voluntarily to meet their common economic, social, and cultural needs and aspirations through jointly owned and democratically controlled enterprise's.

\section{Statement of Problem}

$>$ Despite the increase in the number of the microfinance institutions in Nigeria, access to finance is still considered as one of the major hindrances to women entrepreneurs in Kwara State in particular and Nigeria in general.

Major financial institutions are known to be biased against women, thus the enterprises owned by women are small in size.

Willingness on the part of women to venture into entrepreneurial activities.

\section{Objectives of the Study}

The broad objective of this study is to assess the impact of cooperative microfinance on the performance of the women entrepreneurship in Kwara State. The specific objectives are to:

1. Identify the various sources of fund for the activities of women entrepreneurs in Kwara State, Nigeria.

2. Identify the economic activities practiced by the women entrepreneurs in Kwara state Nigeria.

3. Assess the benefits of cooperative entrepreneurial activities to the women entrepreneurs in Kwara state, Nigeria.

4. Examine the constraints to entrepreneurial activities of the women entrepreneurs in Kwara state, Nigeria.

Significance of The Study. This study may provide a better understanding to cooperative activities embarked upon by women entrepreneurs and the micro financial support enjoyed by being a member of cooperative 
society. Cooperative microfinance institutions, women entrepreneurs and government may benefit from the findings of this study and may help to understand how to improve women entrepreneurship in Nigeria.

The findings may also contribute to the existing knowledge of cooperative microfinance as it relates to women entrepreneurship development.

\section{Literature Review}

Research from many countries indicated that feminines gender's involvement and contribution to entrepreneurial activities cannot be underestimated most especially in developing countries where cultural, and gender stereotype are still more prevalent. In Nigeria, like other developing countries, financial inclusion is more prevalent in the lower strata of the economy including SMEs (Zins \& Weill, 2016). Women participate more in entrepreneurial activities because of their reproductive role, domestic role, stereotype, and cultural belief which often placed women at a disadvantage over their male counterpart. Given the prominent role play by Microenterprises business in terms of employment, and this employment generation often involves more women than men especially in developing countries. This is because women are often found in entrepreneurial activities because of their reproductive role, cultural beliefs, and domestic role which often prevent them from participating in white collar jobs (Olateju, et al., 2017).

Musa (2014) notes that economic growth is a long-term process of sustainable rise in the capacity of a nation to supply increasingly diverse economic goods and services to its growing population. It is conventionally measured by the increase in Gross Domestic Production (GDP) of the country. (CBN,2015). Besides carrying out their domestic chores like food production, firewood collection and provision of household water, reproduction and parenting (motherhood), women contribute significantly to the workforce in agriculture and informal sectors. They constitute one-fourth of developing nations ${ }^{\text {ee }}$ industrial labor force but still carry the main burden of childcare (parenting) and household chores (Roberto, 2015).

However, women carrying out business efficiently and effectively have often been impeded due to lack of capital. To ensure access to capital by women entrepreneurs, past governments in Nigeria had embarked on some programmes and policies to help ameliorate the situations. One of such policies is the wholesale fund which is meant to be given to micro entrepreneurs through microfinance institutions at a lower interest rate with $60 \%$ of the fund given to women (Olateju, et al., 2017).

The empirical of the study are as follows. In the study of Oluwole and Azuh, (2014) on the Impact of Women Entrepreneurs on the Economy of Ota Nigeria, the study sought to find the roles and contributions of women small and medium scale enterprises (SME) operators to the development of the city with 146 women entrepreneurs as respondents. Data collected were analyzed using simple frequency tables and regression analysis. The findings revealed that the extent to which the variance in poverty level can be explained by the activities of women entrepreneurs is $32.3 \%$ ie $(\mathrm{R} 2=.323), \mathrm{F}=6.790$, and $\mathrm{P} \leq 0.001$. This shows that the activities of women entrepreneurs have significant effect on poverty level in Ota Ogun State Nigeria.

According to Ukommi and Agha (2016), regarding factors that inhibit women entrepreneurships or businesses, $14.8 \%$ of the respondents were of the opinion that cultural/religious beliefs inhibit women from successful entrepreneurship, $12.4 \%$ said it was women illiteracy, $11.2 \%$ said it was lack of collaterals, $10.8 \%$ admitted that women were carrying too much household burden, $10 \%$ accused government's inability to provide empowerment to women, $9.2 \%$ said it was overbearing husbandse influence, another 9.2 were of the opinion that there was corruption among implementers of women empowerment policy, while $7.2 \%$ attributed such to bank refusal to give credit to women, and $6.8 \%$ said it was women's nonchalant attitude. $8.4 \%$ were of the opinion that there are other factors, apart from those enumerated that inhibits women entrepreneurship in Nigeria

In spite of all these measures to enhance women entrepreneurship, many of women entrepreneurs in Nigeria still find it difficult to get access to some of these funds. For instance, according to the EFinA report in 2014, out of the 36.9 million adults in Nigeria who are financially excluded, $57.9 \%$ are female while $42.1 \%$ are male. These figures indicate that more female is financially excluded than their male counterpart. Also, at the state level, Lagos State is still one of the top ten states in Nigeria with financially excluded person (EFinA, 2014). A lack of own transport could also negatively impact a woman's business venture. As the (UN, 2014) puts it, often spouses discourage the women from travelling alone and even using public transport as it may expose the women to sexual harassment and other prejudices. However, women face extra specific challenges because of societal stereotypes (Choto et al., 2014). 
Umeh et al., (2017), the study identified entrepreneurial activities carried out by the women cooperators; sources of fund for their activities, ascertain contributions of co-operative entrepreneurial activities to the women as well as ascertained strategies used by the women co-operatives in promoting entrepreneurship. The study also identified constraints to entrepreneurial activities the women co-operatives such as poor government intervention, low level of exposure to proper training and lack of financial power (Umeh, et al., 2017).

Given the fact that microenterprises sector has the potential to employ more women than men because of the inability of most women in participating in white collar jobs due to their reproductive role, domestic role stereotype and cultural believes. Therefore, access to capital for women entrepreneur is paramount, as the inability of women entrepreneur to gain access to credit could reduce the employment opportunities available for women in this sector, thereby leading to unemployment and high poverty rate among women (Olateju, et al., 2017).

Anyiro et al. (2014) used a multistage random sampling technique to select 120 members of women self-help group in Iswikwuata area of Abia State, Nigeria. The data were analysed through a probit regression, and the result of the probit regression indicates that women participation in self-help group micro credit was determined by the size of the household, membership experience, access to credit, primary occupation, mode of entry and their annual contributions.

Shah and Panigrahi (2015) used a logit regression estimate and found that factors that play an important role in determining women's participation in a Self-Help Group (SHG) credit programme are household head status, age. Education, the number of children born by respondents, means of generating income, case, informal debt, proximity to banks, migration and financial capability of the household.

The Identified Gap in Literature. The impact of cooperative microfinance on the performance of women entrepreneurs in Kwara State as hub of entrepreneurial activities have not been given proper consideration for discuss or analysis by any study. It has not also been given proper attention by any literature, this study is therefore very imperative. In order to get a clear view of previous studies, the following summary is presented in table 2.1 below:

Table 1. Summary of previous studies on the impact of Microfinance on the Performance of women Entrepreneurship

\begin{tabular}{|c|c|c|c|c|c|c|}
\hline Authors & Article Title & $\begin{array}{l}\text { Sample } \\
\text { Size }\end{array}$ & $\begin{array}{l}\text { Time } \\
\text { Horizon }\end{array}$ & $\begin{array}{l}\text { Independent } \\
\text { Variables } \\
\text { Measurement }\end{array}$ & $\begin{array}{c}\text { Dependent } \\
\text { Variables } \\
\text { Measurement }\end{array}$ & $\begin{array}{l}\text { Method of } \\
\text { Estimation }\end{array}$ \\
\hline $\begin{array}{l}\text { Oluwole, I. and } \\
\text { Azuh, D. }\end{array}$ & $\begin{array}{l}\text { Women Entrepreneurs as } \\
\text { Small-Medium Enterprises } \\
\text { (SME) operators and Their } \\
\text { Roles in Socio-Economic } \\
\text { Development in Ota, Nigeria }\end{array}$ & 146 & $\begin{array}{l}\text { Cross- } \\
\text { sectional } \\
(2014)\end{array}$ & $\begin{array}{l}\text { Women } \\
\text { Entrepreneurs } \\
\text { Activities }\end{array}$ & $\begin{array}{l}\text { Poverty Level } \\
\text { Access to Fund } \\
\text { Apathy towards } \\
\text { Business }\end{array}$ & $\begin{array}{l}\text { Logistic } \\
\text { Regression } \\
\text { Analysis }\end{array}$ \\
\hline $\begin{array}{l}\text { Anyiro, C.O., } \\
\text { Ajuka, P.N., } \\
\text { Emerole, C.O. and } \\
\text { Orji, I.E. (2014), }\end{array}$ & $\begin{array}{l}\text { "Determinants of women's } \\
\text { participation in self help group } \\
\text { led micro-financing of farms in } \\
\text { Isuikwuato Local Government } \\
\text { area of Abia State, Nigeria }\end{array}$ & 120 & $\begin{array}{l}\text { Corss- } \\
\text { sectional } \\
(2014)\end{array}$ & $\begin{array}{l}\text { Self-Help Group } \\
\text { Primary } \\
\text { Occupation }\end{array}$ & $\begin{array}{c}\text { Access to Credit } \\
\text { Size of Household } \\
\text { Types of Business }\end{array}$ & $\begin{array}{l}\text { Probit } \\
\text { Regression } \\
\text { Method }\end{array}$ \\
\hline $\begin{array}{l}\text { Ukommi, A. S. and } \\
\text { Agha, E. O (2016), }\end{array}$ & $\begin{array}{l}\text { Women Entrepreneurship in } \\
\text { Nigeria: A Study of Women in } \\
\text { Uyo Metropolis }\end{array}$ & 208 & $\begin{array}{l}\text { Cross- } \\
\text { sectional } \\
(2016)\end{array}$ & $\begin{array}{c}\text { Access to External } \\
\text { Help }\end{array}$ & $\begin{array}{l}\text { Age of Business } \\
\text { Running just one } \\
\text { business }\end{array}$ & $\begin{array}{c}\text { Simple } \\
\text { Frequency } \\
\text { Table \& } \\
\text { Percentage } \\
\end{array}$ \\
\hline $\begin{array}{l}\text { Umeh, O. J., Agu- } \\
\text { Aguiyi, F. N. and } \\
\text { Ekumankama, O. O. }\end{array}$ & $\begin{array}{l}\text { Effect of Women Co-operative } \\
\text { Activities on Entrepreneurship } \\
\text { Development of Members in } \\
\text { Abia State Nigeria }\end{array}$ & 109 & $\begin{array}{l}\text { Cross- } \\
\text { sectional } \\
(2017)\end{array}$ & $\begin{array}{c}\text { Women Economic } \\
\text { Activities }\end{array}$ & $\begin{array}{l}\text { Sources of Fund } \\
\text { Cooperative } \\
\text { Strategies }\end{array}$ & $\begin{array}{c}\text { Frequency \& } \\
\text { Percentage } \\
\text { Tables/ } \\
\text { Inferential } \\
\text { Statistic Tools } \\
\end{array}$ \\
\hline EFInA & $\begin{array}{l}\text { Enhancing Financial Innovation } \\
\text { and Access in Nigeria (EFInA) } \\
2014 \text { Survey }\end{array}$ & $\begin{array}{c}36.9 \mathrm{mi} \\
\text { llion }\end{array}$ & $\begin{array}{l}\text { Longitudin } \\
\text { al (2014) }\end{array}$ & $\begin{array}{c}\text { Women } \\
\text { Entrepreneurship }\end{array}$ & $\begin{array}{l}\text { Access to funds } \\
\text { Access to proper } \\
\text { training }\end{array}$ & $\begin{array}{c}\text { Frequency \& } \\
\text { Percentage } \\
\text { Tables } \\
\end{array}$ \\
\hline $\begin{array}{l}\text { Olateju, O. Aminu, } \\
\text { A.W., Shehu, A\& } \\
\text { Danmola, R.A. }\end{array}$ & $\begin{array}{l}\text { The determinants of women } \\
\text { entrepreneurs' access to micro } \\
\text { credit programme: A case study } \\
\text { of Cowries Microfinance Bank } \\
\text { (CMB) Lagos, Nigeria }\end{array}$ & 359 & $\begin{array}{c}\text { Cross- } \\
\text { Sectional } \\
(2017)\end{array}$ & Credit programme & $\begin{array}{c}\text { Binary response } \\
\text { function } 0 \text { or } 1 \\
\text { (Participant/Non- } \\
\text { participant) }\end{array}$ & $\begin{array}{c}\text { Probit } \\
\text { Regression } \\
\text { Method }\end{array}$ \\
\hline
\end{tabular}

Source: Author's Compilation, 2018

\section{Methodology}

This study was carried out in Kwara State, Nigeria. It is located in the agro-ecological zone of the country. 
Kwara State made up of four ethnic groups namely; Yoruba, Nupe, Fulani and Baruba. The state lies between latitudes $7045^{\prime} \mathrm{N}$ and $9030^{\prime} \mathrm{N}$ and longitudes $2030^{\prime} \mathrm{E}$ and $6035^{\prime} \mathrm{E}$. The population of the state is predominantly farmers that specialized in arable crops such as groundnut, shorgum, cassava, yam, cowpea, maize, yam and rice. Kwara State occupies 36,825 square kilometers with a total population of 2,371,089 persons made up of 1,193,783 males and 1,171,570 females. (NPC, 2006).

The study employed a multi stage sampling technique in the selection of women entrepreneurs. Two Women Cooperative Microfinance Associations were purposively selected out of the list of Women Cooperative Associations that are registered with the Ministry of Commerce, Kwara State i.e Women Cooperative Alliance Limited and Amuludun Women Oke-Onigbin Fadama Resource Users Cooperative Society Limited. The choice of these two Women Cooperative Associations was informed by the fact that they have their membership list, members can be located for interview and they have records of regular cooperative activities such as meetings and group visitations. For equal representation,

The data were analyzed using both descriptive statistical tools (frequencies and percentages) and inferential statistical tools (Pearson Correlation analysis).

Variables Determination. To identify the economic activities practiced by the women entrepreneurs in cooperative societies, a list of different women economic activities such as farming, Animal husbandry, poultry keeping, Fadama, Agro-processing, bead making, trading among others were listed. Respondents were asked to indicate variables of their choice and their responses were collated in a frequency table. To identify the sources of fund for the activities of the women entrepreneurs in cooperative societies, a list of possible sources of fund for the cooperative societies such as share capital, members' contribution, fines, entrance fees were listed. Respondents were asked to indicate variables of their choice and their responses were collated in a frequency table.

To ascertain contributions of co-operative entrepreneurial activities to the development and sustenance of women, the women were asked to indicate the level/extent of benefits/contribution of the selected variables to them on a five point Likert type scale of: to a very great level $=5$, to a great level $=4$, to little level $=3$, to very little level $=2$ and to no level $=1$. The values were summed to get 15 and divided to get 3 as mean. Variables with the mean of greater than or equal to 3 were seen as a contribution/benefit of co-operative entrepreneurial activities to the women. Respondents were asked to indicate the level of seriousness of each challenge on a five point Likert type scale of: to a very great level $=5$, to a great level $=4$, to little level $=3$, to very little level $=2$ and to no level $=1$. The values were summed to get 15 and divided to get 3 as mean.

Variables with the mean of greater than or equal to 3 were seen as possible constraints to execution of entrepreneurial activities for the women co-operatives in the study area.

\section{Results and Discussion}

Sources of fund for the activities of the women entrepreneurs in cooperative societies. From Table 1 , the representation of the sources of fund for cooperative societies was spelt out. From the respondents, 65.34\% were of the opinion that their cooperatives sourced or raise its fund from members' contribution, $82.39 \%$ (share capital). Other sources of finance include Fines and levies $(55.68 \%)$, new entrants $(32.37 \%)$ and Funding from Government \& NGOs (18.18\%). This implies why these women entrepreneurs in cooperative societies are faced with financial constraints, having relied more on the financial power of their share capital and other contribution from members. They receive little assistance from external source financing.

Table 2. Response according to source of finance of Microfinance cooperative society (multiple responses)

\begin{tabular}{|l|c|c|c|}
\hline \multicolumn{1}{|c|}{ S/No. } & Variables & Frequencies & Percentage (\%) \\
\hline 1 & Funding from Government \& NGOs & 32 & 18.18 \\
\hline 2 & Fines \& levies & 98 & 55.68 \\
\hline 3 & Share capital & 145 & 82.39 \\
\hline 4 & New Entrants & 57 & 32.37 \\
\hline 5 & Individual Contribution & 115 & 65.34 \\
\hline
\end{tabular}

Economic activities practiced by the women entrepreneurs in cooperative societies. From Table 2, Fadama operation (48.86\%), Arable crop farming (61.93\%), and agro-processing (Rice processing, Gari, fish processing, etc) $(57.95 \%)$ are the major economic activities practiced by the women cooperative societies in the study area. Others are poultry keeping (14.20\%), Confectioneries (Doughtnut, Pie, Cakes, chinchin, etc) $(21.02 \%)$, thrift and credit (40.34\%) and small-scale trading (22.16\%) and restaurant operation (15.91\%). 
They pool their resources together and engage in these entrepreneurial activities as source income to their cooperatives.

Table 3. Activities' distribution of women entrepreneurship in Microfinance cooperative societies (multiple responses)

\begin{tabular}{|c|c|c|c|}
\hline S/No. & Variables & Frequency & Percentage (\%) \\
\hline 1 & Fadama Operation & 86 & 48.86 \\
\hline 2 & Thrift \& Credit & 71 & 40.34 \\
\hline 3 & Poultry keeping & 25 & 14.20 \\
\hline 4 & Animal husbandry & 63 & 35.80 \\
\hline 5 & Arable Crop & 109 & 61.93 \\
\hline 6 & Confectioneries (Doughtnut, Pie, Cakes, chinchin, etc) & 37 & 21.02 \\
\hline 7 & $\begin{array}{c}\text { Agro-processing (Rice processing, Gari, fish } \\
\text { processing, etc) }\end{array}$ & 102 & 57.95 \\
\hline 8 & Small Scale Trading & 39 & 22.16 \\
\hline 9 & Restaurant operation & 28 & 15.91 \\
\hline
\end{tabular}

Source: Field survey December, 2017.

Microfinance Co-operative entrepreneurial activities' benefits to the women. Table 3 presents mean of benefits accrued from co-operative entrepreneurial activities to the women. Data from the table indicated that Skill Acquisition ( = 3.70), Group Development $(=3.65)$, Group and membership increment $(=4.63)$ and Economic Growth and Development $(=3.64)$ are major benefits and contributions of co-operative entrepreneurial activities to the women cooperators while others are poverty Alleviation $(=2.89)$ and Community Development $(=2.80)$. Women entrepreneurship help women to own businesses, generate more income which then can be used to improve themselves and support their households as well as offer employment to others in their community. The women engaging in cooperative for developing and sustain their entrepreneurial work are very hard working and meticulous in their activities. They solely rely on the information and finance available to them to ensure better standard of living for them and their family. Women are afforded opportunities to create their own businesses and make adequate use of their acquired skills and training. Ayogu and Agu (2015) agreed that job creation both for the women and others can be a panacea for the increasing unemployment/under employment rate in the country while Badiru, (2014) agreed that participation in cooperative activities can afford cooperators access to initial capital for starting business which can reduce the level of poverty among them.

Table 4. Benefits of microfinance co-operative entrepreneurial activities to the women

\begin{tabular}{|l|c|c|c|}
\hline \multicolumn{1}{|c|}{ Variables } & Total & Mean () & SD 0 \\
\hline Self Actualization & 649 & $3.69^{*}$ & 1.08950 \\
\hline Skill Acquisition & 701 & $3.98^{*}$ & 0.62628 \\
\hline Job Creation & 654 & $3.72^{*}$ & 1.16686 \\
\hline Group Development & 706 & $4.01^{*}$ & 0.92312 \\
\hline Poverty Alleviation & 588 & $3.34^{*}$ & 1.05944 \\
\hline Economic Growth \& Development & 641 & $3.64^{*}$ & 1.21180 \\
\hline Group/Membership Increment & 815 & $4.63^{*}$ & 0.50567 \\
\hline Community Development & 624 & $3.55^{*}$ & 1.10998 \\
\hline Infrastructural Development & 491 & 2.79 & 1.20828 \\
\hline
\end{tabular}

Source: Field Survey December, 2017.

Constraints to entrepreneurial activities of the women co-operatives. Data from Table 4 indicate that women co-operatives are Inadequate finance $(=4.87)$, Lack of Access to raw materials $(=4.76)$, Maladministration of fund $(=4.65)$, Inadequate Market Information $(=4.58)$, Lack of good coordination $(=$ 4.31). Other are Lack of adequate and proper training for projects $(=4.10)$, Bad Leadership $(=4.09)$. Other low constraints are Lack of infrastructures $(=3.60)$, Illiteracy $(=3.00)$ and Absence of Extension Agents $(=$ 2.91). This outcome corroborates the findings of Badiru et al. (2016) who reported that low knowledge about the guiding principles of cooperatives and poor leadership causes improper coordination of activities which is also among major challenges to active participation in cooperative activities. It is also in line with the confession of Apesughur et al., (2014) which reported that mismanagement of fund constituted a major constraint to participation of cooperators in cooperative activities he conducted. Financial exclusion on the part of women in entrepreneur arises due high risk associated to the business or poor project quality, while others are due to market imperfections such as asymmetric information arising from lack of credit worthiness of the prospective clients are voluntary excluded despite being bankable (Stiglitz \& Weiss, 2016). 
Table 5. Respondents response on Constraints to entrepreneurial activities of the women co-operatives

\begin{tabular}{|l|c|c|c|}
\hline \multicolumn{1}{|c|}{ Variables } & Total & Mean () & SD () \\
\hline Maladministration of Fund & 819 & $4.65^{*}$ & 0.49920 \\
\hline Lack of Infrastructures & 633 & $3.60^{*}$ & 0.33705 \\
\hline Inadequate Finance & 857 & $4.87^{*}$ & 0.59775 \\
\hline Inadequate Market Information & 806 & $4.58^{*}$ & 0.80184 \\
\hline Lack of good coordination & 759 & $4.31^{*}$ & 1.27475 \\
\hline Illiteracy & 528 & $3.00^{*}$ & 0.85462 \\
\hline Bad Leadership & 720 & $4.09^{*}$ & 0.85067 \\
\hline $\begin{array}{l}\text { Lack of adequate and proper training for } \\
\text { projects }\end{array}$ & 721 & $4.10^{*}$ & 0.59342 \\
\hline Lack of Access to Raw Materials & 838 & $4.76^{*}$ & 1.35203 \\
\hline Absence of Extension Agents & 513 & 2.91 & \\
\hline
\end{tabular}

Source: Field survey December, 2017.

\section{Conclusion}

Findings from the study indicate that Fadama Operation, Thrift \& Credit, Poultry keeping, Animal husbandry, Arable Crop, Confectioneries (Doughtnut, Pie, Cakes, chinchin, etc), Agro-processing (Rice processing, Gari, fish processing, etc), Small Scale Trading, Restaurant operation are major activities the women entrepreneurs are involved in making a meaningful living out of life. . Group Development, Poverty Alleviation, Skill Acquisition, Self Actualization, Group/Membership Increment, Job Creation, Economic Growth \& Development, and Community Development are major giver of development and sustenance to co-operative entrepreneurial activities of the women cooperators.

However, Maladministration of Funds, Lack of Infrastructures, Inadequate Finance, Inadequate Market Information, Illiteracy, Lack of good coordination, Bad Leadership, Lack of adequate and proper training for projects and Lack of Access to Raw Materials are major cog in the success wheel of the activities of the women entrepreneurs. Improvement on the activities used by women co-operatives in promoting entrepreneurship among members will also enhance the benefits or contributions of co-operative entrepreneurial activities to the women cooperators.

\section{Recommendations}

Women entrepreneurs in Nigeria and other countries are major contributors to economic growth and employment creation for the people (Iyiola \& Azuh, 2014).

Empowering women economically in Nigeria is a key factor in improving the economy. This is one of the reasons for Nigeria to seek for more empowerment for women entrepreneurs to promote rapid economic development (Adetoyinbo, 2015). More so, there must be sustained entrepreneurship training /education for women cooperatives by the government and NGOs. Financial, environmental, psychological, and sociological factors are elements that are able to either encourage or discourage women in entrepreneurship. Hence, women entrepreneurial motivation is considered as an interaction between economic, social, psychological and environmental factors as well as a willingness on the part of women to venture into entrepreneurial activity (Moses, Olokundun and Akinbode, 2014). The feminization of poverty should also be brought to an abrupt end in the area. Also, pragmatic and community-based relations development measures should be taken to develop the women and the area as supposed.

The women should be sensitized towards having interest in entrepreneurial and agricultural ventures rather than clustering in (petty) trade. Equal education opportunity for women in addition to the provision of schools and regular sensitization would do those women a lot of good, which would raise their contribution to economic development and alleviate their poverty.

\section{References}

1. Abiola, B. (2015). Effects of Microfinance on Micro and Small Enterprises (MSEs) Growth in Nigeria. Asian Economic and Financial Review, 2(4), pp.49-58.

2. Amenya L.M. and Ombui K.A. (2016). Determinants of financial performance of savings and credit cooperative societies in Kiambu County, Kenya, International Journal of Social science and information Technology, 2(9), pp.78-99.

3. Anyiro, C.O., Ajuka, P.N., Emerole, C.O. and Orji, I.E. (2014). "Determinants of women's participation in self help group led micro-financing of farms in Isuikwuato Local Government area of Abia State, 
Nigeria", Scientific Papers Series Management, Economic Engineering in Agriculture and Rural Development, 14(3), pp. 21-29.

4. Apesughur, D. A., Ashiki, G. M., Kim, I., Yusuf, K (2014). Assessment of self-help initiatives and the development of rural communities in Agatu Local Government Area of Benue State, Nigeria. Global Journal of Agricultural Economics, Extension and Rural development, 8(3), pp. 45-48.

5. Ayogu, D. U. and Agu, E. O. (2015). Assessment of the Contribution of Women Entrepreneur towards Entrepreneurship Development in Nigeria. International Journal of Current Research and Academic Review, 3(10), pp. 190-207.

6. Badiru, I. O, Y usuf, S. K and Anozie, O. (2016). Adherence to Cooperative Principles among Agricultural Cooperatives in Oyo State, Nigeria. Journal of Agricultural Extension, 20(1) pp. 8-9.

7. Central Bank of Nigeria (2015). Financial Stability Report - December 2015.

8. Choto, P., Tengeh, R.K.; Iwu, C.G. (2014). Daring to survive or to grow? The growth aspirations and challenges of survivalist entrepreneurs in South Africa. Environmental Economics, 4(5), pp.93-101.

9. Dibie,G. A. (2017), "Obiaruku Women and Economic Development", International Journal of Engineering andInformation Systems(IJEAIS), 1 (8), pp. 124-134.

10. Dibie, G.A., Besong, E.N., \& Robert, O.S. (2015). Cultural effects on entrepreneurship development: $A$ focus on Lafia. Journal of Humanities and Social Sciences, 4(4), pp. 33.

11. EFInA (2014), Enhancing Financial Innovation and Access in Nigeria (EFInA) 2014 Survey, available at: $\mathrm{http} / /$ www.efina.org.ng/assets/Documents/EFInA-Access-to-Financial-Services-in-Nigeria-2014Survey-Key-Findings.pdf (accessed December, 18 2017).

12. Food and Agricultural Organization (FAO). 2016. Promoting rural women's cooperative businesses in Thailand. A training kit. pp 3-4.

13. John-Akamelu C. R. and MuogboUju S. (2017). The Contributions of Women Entrepreneurs In SocioEconomic Development (A study of selected local governments in Anambra state Nigeria), Business and Management Research Journal Vol. 7(6): 58-65.

14. Musa, N. (2014). An empirical investigation of the impact of entrepreneurship on sustainable economic growth in Nigeria. The International Journal of Entrepreneurial Studies, 6 (2), pp. 63

15. Ochelle, J.O. (2014). Women in the rural economy of Igede land since 1960. A research proposal submitted to the Department of History, BSU, Makurdi.

16. Odetayo, T. A (2016). Significance of Microfinance Banks in Financing Small Scale Enterprises in Selected Local Government Areas of Osun State Nigeria. Journal of Accounting and Finance Management, 2(3), 12-22.

17. Olateju, A.O., Aminu, A.W., Shehu, A. and Danmola, R.A. (2017), The determinants of women entrepreneurs' access to micro credit programme: A case study of Cowries Microfinance Bank (CMB) Lagos, Nigeria, International Journal of Development and Sustainability, 6 (8), pp. 783-791.

18. Oluwole, I. and Azuh, D. (2014). Women Entrepreneurs as Small-Medium Enterprises (SME) operators and Their Roles in Socio-Economic Development in Ota, Nigeria". International Journal of Economics, Business and Finance, 2 (1), pp. 1-10.

19. Phelps, B. E. S. (2016). American Economic Association the Statistical Theory of Racism andSexism Author (s): Edmund S. Phelps Source: The American Economic Review, 62(4), pp. 659-661.

20. Popoola Mufutau Akanmu (2012). Women Cooperatives in Ife North Local Government Area of Osun state. (a case study of Asipa and Akinlalu Women Cooperative Societies). Unpublished B.Sc. project at National Open University of Nigeria (NOUN).

21. Popoola Mufutau Akanmu (2018). The Impact of Entrepreneurship practice on Poverty Reduction in Nigeria: Evidence from Osun state. International Journal of Advance Research and Innovative Ideas in Education,4(3), pp.762-767.

22. Robert, O.S. (2015). Situating the Bekwarra Women's place inpolitics, ethics, culture and economy in Nigeria. Available at academia.edu. (accessed December 17, 2017).

23. Shah, D. and Panigrahi, S. (2015). Determinants of participation of women in Self-Help Groups (SGHs) and credit delivery from formal and informal sources to BPL households in Odisha, Indian Journal of Agricultural Economics, 70(3), pp. 405-416.

24. Stiglitz, B. J. E., \& Weiss, A. (2016). American Economic Association Credit Rationing in Marketswith Imperfect Information Author(s): Joseph E. Stiglitz and Andrew Weiss Published by: American Economic Association Stable URL: http://www.jstor.org/stable/1802787 Your use ofthe JSTOR arc, 71(3), 393410.

25. Ukommi, A. S. and Agha, E. O (2016), Women Entrepreneurship in Nigeria: A Study of Women in Uyo Metropolis. International Journal of Social Sciences, 10 (4), pp. 103-104. 
26. United Nations (2014), Empowering Women Entrepreneurs through Information and Communications Technologies; United Nations: Geneva, Switzerland.

27. Umeh, O. J., Agu-Aguiyi, F. N. and Ekumankama, O. O. (2017), Effect of Women Co-operative Activities on Entrepreneurship Development of Members in Abia State Nigeria, Nigerian Journal of Agriculture, Food and Environment, 13(1), pp. 80-85.

28. Zins, A., \& Weill, L. (2016). The Determinants of Financial Inclusion in Africa. Journal of Advanced Research, 6(1), pp.46-57. 